\title{
Postsettlement growth of two estuarine crab species, Chasmagnathus granulata and Cyrtograpsus angulatus (Crustacea, Decapoda, Grapsidae): laboratory and field investigations
}

Received: 27 April 2001 / Received in revised form: 20 September 2001 / Accepted: 20 September 2001

Published online: 14 November 2001

(C) Springer-Verlag and AWI 2001

\begin{abstract}
The estuarine grapsid crabs Chasmagnathus granulata and Cyrtograpsus angulatus belong to the most typical and dominant inhabitants of brackish coastal lagoons in southeastern South America. In a combined laboratory and field investigation of juvenile growth, we measured the increase in body size in these species under controlled conditions as well as in field experiments (in Mar Chiquita lagoon, Argentina), seasonal changes in size frequency distribution of a natural population, and growth related changes in selected morphometric traits of male and female juveniles (relations between carapace width, carapace length, propodus height and length of the cheliped, and pleon width). At $24^{\circ} \mathrm{C}, \mathrm{Cy}$. angulatus grew faster than Ch. granulata; it reached the crab-9 instar (C9; $13 \mathrm{~mm}$ carapace width) after 92 days, while Ch. granulata required 107 days to reach the $\mathrm{C} 8$ instar $(7.4 \mathrm{~mm})$. At $12^{\circ} \mathrm{C}$, growth ceased in both species. The pleon begins to show sexual differences in the C5 (Cy. angulatus) and C8 instar (Ch. granulata), respectively, while the chelae differentiate earlier in Ch. granulata than in Cy. angulatus (in $\mathrm{C} 4$ vs C6). In the field, growth was maximal in summer, and was generally faster than in laboratory cultures. However, there is great individual variability in size (about 25\% even in the first crab instar) and in size increments at ecdysis, increasing throughout juvenile growth. Our data indicate that, in the field, small-scale and shortterm variations in feeding conditions, temperature, and salinity account for an extremely high degree of variability in the absolute and relative rates of growth as well as in the time to sexual differentiation.
\end{abstract}

Communicated by H.-D. Franke

T.A. Luppi $(\bowtie) \cdot$ E.D. Spivak

Departamento de Biología,

Facultad de Ciencias Exactas y Naturales,

Universidad Nacional de Mar Del Plata, Casilla de Correo 1245,

7600 Mar del Plata, Argentina

e-mail: taluppi@mdp.edu.ar

K. Anger

Biologische Anstalt Helgoland,

Stiftung Alfred-Wegener-Institut für Polar- und Meeresforschung, 27483 Helgoland, Germany
Keywords Allometry · Crab · Grapsidae · Juvenile . Sexual dimorphism

\section{Introduction}

The growth of crustaceans appears as a discontinuous process, as the hard exoskeleton is periodically replaced in successive ecdyses, followed by postmolt uptake of water and, in consequence, a rapid increase in body size during the short soft-skinned period. Hence, growth rates depend on two principal components, (1) the size increment after molting, (2) the duration of the intermolt period (Kurata 1962; Klein Breteler 1975; Hartnoll 1982; Restrepo 1989; Tweedale et al. 1993). The intermolt period usually increases with size, while the percentage increment tends to decrease.

In the field, growth is usually studied indirectly, through the analysis of size frequency distributions, assuming that no major immigrations or emigrations take place in a population during the period of investigation (Hartnoll 1982). Under controlled conditions in the laboratory, in contrast, intermolt periods and size increments can be studied in identical individuals, allowing for precise quantitative descriptions of growth. On the other hand, laboratory conditions are artificial and may thus not allow for full extrapolation of experimental data to field populations. Attempting to compensate for some of those limitations, we chose a combined approach of laboratory and field studies in this investigation.

In crabs, various morphological structures such as the carapace, claws, walking legs, or the pleon may show differential rates of growth. Changes in allometric relations between different body dimensions have extensively been studied in field-collected individuals (e.g. Kurata 1962; Mauchline 1977; Hartnoll 1982), while fewer reports deal with morphometric changes in safely identified successive instars (Anderson and Ford 1976; Yatsuzuka and Meruane 1987; Tunberg and Creswell 1991). This bias was attributed to difficulties in the collection, identification, and subsequent rearing of juve- 
niles (Hebling et al. 1982; Negreiros-Fransozo and Fransozo 1991), which render ecological research on the functional importance of juveniles in their natural habitats generally difficult (O'Connor 1990). In the present study, we measured growth in various body dimensions both in field-caught and laboratory-reared crabs, with emphasis on sexual differences in morphometric relations.

Grapsid and ocypodid crabs are characteristic and frequently dominant inhabitants of the intertidal and supratidal zones of tropical and temperate estuaries and brackish coastal lagoons (Pillay and Ono 1978; Seiple 1979; Willason 1981; Jones and Simons 1982; Seiple and Salmon 1987; Spivak et al. 1994). Representing typical examples, Chasmagnathus granulata and Cyrtograpsus angulatus (Grapsidae) are considered as key species in "cangrejal" saltmarsh ecosystems (from Spanish, cangrejo $=\mathrm{crab}$ ), which are widespread along the warmtemperate southwestern Atlantic coasts (Boschi 1964, 1988). In the intertidal zone of Mar Chiquita, Argentina, the southernmost in a series of brackish coastal lagoons extending along the coasts of southern Brazil, Uruguay and northeastern Argentina, these two species co-occur with dense populations (Olivier et al. 1972; Spivak et al. 1994). Adult Cy. angulatus are predominantly found in the lower intertidal and the adjacent subtidal, but occur also on rocky open sea shores. Ch. granulata digs burrows in muddy substrates, preferably in the upper intertidal and supratidal zones fringing saltmarshes.

In Mar Chiquita, reproduction takes place from September to May in Cy. angulatus, and from October to March in Ch. granulata, with several egg clutches produced during each season (Spivak et al. 1996). According to plankton studies, newly hatched zoea-I larvae are exported from the lagoon, later zoeal development takes place in coastal marine waters, and the megalopa stage returns for settlement into the lagoon (Anger et al. 1994). Settlers and early juveniles of $C y$. angulatus are predominantly found in crevices of sand "reefs" which are constructed by Ficopomatus enigmaticus, a tube-building polychaete, and in other sheltered microhabitats, e.g. under stones and between empty mollusc shells. Young Ch. granulata, in contrast, are frequently found on muddy bottoms, especially inside and around the burrows of conspecific adults (Boschi 1964; Spivak et al. 1994; Luppi et al. 1994).

Although ecological and physiological traits of $C y$. angulatus and Ch. granulata are well documented for the larvae (Boschi et al. 1967; Anger et al. 1994; Anger and Ismael 1997; Ismael et al. 1997; Gebauer et al. 1998; Valero et al. 1999) and for the adult phase of the life cycle (Spivak and Politis 1989; Gavio and Spivak 1994; Spivak et al. 1994, 1996; Luppi and Spivak 1996; Iribarne et al. 1997; Luppi et al. 1997; Lopez Greco and Rodriguez 1998; Luppi 1999; Spivak 1999), much less information is available on the juvenile phase (Spivak 1988; Rieger and Nakagawa 1995; Anger and Ismael 1997; Lopez and Rodriguez 1998; Gebauer et al. 1999). The principal aim of the present paper is thus to quanti- tatively describe the juvenile growth of these species. This includes (1) the absolute and relative patterns of growth under controlled laboratory conditions, (2) sexual and size-dependent changes in morphometric relations, and (3) estimates of growth in the field.

\section{Materials and methods}

\section{Study area}

Mar Chiquita lagoon $\left(37^{\circ} 32^{\prime}-37^{\circ} 45^{\prime} \mathrm{S} / 57^{\circ} 19^{\prime}-57^{\circ} 26^{\prime} \mathrm{W}\right)$ covers an area of $46 \mathrm{~km}^{2}$. A few small rivers feed it with freshwater, while seawater enters and leaves it periodically with semidiurnal high tides. The extent of water exchange depends on the tidal amplitude and the direction and speed of winds (Olivier et al. 1972; Reta et al. 1997). Water temperature (Fig. 1) and salinity show strong seasonal, daily and local variations (Anger et al. 1994; Marcovecchio et al. 1997; Martos and Reta 1997).

\section{Collection and rearing techniques}

Megalopae of $C y$. angulatus and Ch. granulata were collected during March 1996 in their respective settlement habitats and subsequently transported to the laboratory. Thirty megalopae were transferred individually to $100 \mathrm{ml}$ plastic bowls with $80 \mathrm{ml}$ water (23\% salinity), which was prepared by the addition of freshwater
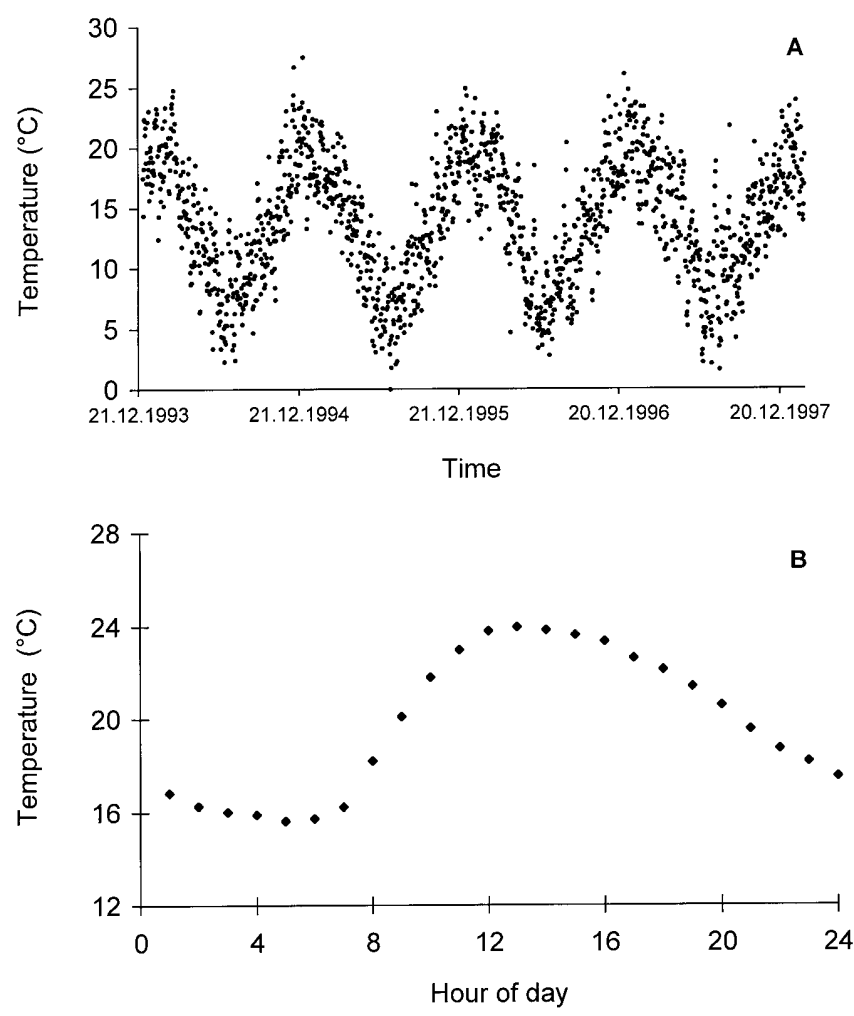

Fig. 1A, B Temperature conditions in Mar Chiquita lagoon. A Seasonal and interannual variations of average daily air temperatures during the study period, from 1993 to the end of the last field experiment (March 1998); the dates in the x-axis indicate the beginning of the austral summer; B Daily variation of air temperature (hourly mean values); data from the meteorological station at Camet airport, $30 \mathrm{~km}$ south of Mar Chiquita lagoon (courtesy National Meteorological Service) 
to inshore seawater $(34 \%$ ) , both previously filtered $(10 \mu \mathrm{m})$. The cultures were maintained at constant $24^{\circ} \mathrm{C}$ and a $16: 8 \mathrm{~h}$ light:dark photoperiod. The water was changed on alternate days and nauplii of Artemia sp. were added as food. Juveniles with $\geq 5 \mathrm{~mm}$ carapace width were transferred to $250 \mathrm{ml}$ plastic bowls. All individuals were checked daily for molting or mortality. Exuviae and dead individuals were stored individually in $4 \%$ formaldehyde.

\section{Growth measurements}

From each exuvia, the following measurements were taken using a stereomicroscope with an ocular micrometer or, in larger crabs, a caliper $(0.01 \mathrm{~mm}$ precision): maximum carapace length $(\mathrm{CL})$, maximum carapace width (CW; in $C y$. angulatus including the lateral spines), maximum cheliped height $(\mathrm{CHH})$ and length (CHL) measured in the propodus, and maximum pleon width (PW) measured in the fourth somite. From these data, percentage size increments (PSI) were calculated. Sex was determined from pleon and pleopod morphology. Successive crab instars were named C1, C2, etc. Relationships between body measurements (logarithmically transformed), PSI, and intermolt periods (IP) in successive instars were analysed with least-square regressions, and slopes of regression equations were compared using ANCOVA (Zar 1984).

For morphometric analyses, quotients between body dimensions (CW, CL, CHH, CHL, PW) were calculated as relative growth indices (RGI) in each instar. Sexual differences between RGI values of successive instars were statistically tested using a non-parametric Mann-Whitney rank test, because the data did not always fulfill the assumptions of normality and homogeneity (Zar 1984). Additionally, larger juveniles and adults were collected by hand in Mar Chiquita and sorted according to size (CW) and sex. From these samples, 20 males and 20 females belonging to each of the following size-classes were selected: $10 \pm 1,15 \pm 1$, $20 \pm 2,30 \pm 2 \mathrm{~mm}$ (Ch. granulata); $15 \pm 1.5,20 \pm 2,30 \pm 2,40 \pm 3 \mathrm{~mm}$ (Cy. angulatus). CW, CL, CHH, CHL and PW were measured and used for the calculation of RGI values.

\section{Effects of temperature on growth}

In January 1996, megalopae of both species were collected in Mar Chiquita, transported to the laboratory, and placed in 31 containers with water of $23 \%$ o salinity. Immediately after molting, 15 crabs of each species were placed individually in $100 \mathrm{ml}$ plastic bowls and reared at $21^{\circ} \mathrm{C}$ and $12^{\circ} \mathrm{C}, 23 \% \circ \mathrm{S}$, and a $16: 8 \mathrm{~h}$ light:dark photoperiod. Crabs were fed with Artemia sp. nauplii every $48 \mathrm{~h}$, after each water change. The presence of exuviae was recorded daily. $\mathrm{CW}$ was measured after 30 days, and mean size values were compared using a Mann-Whitney $U$ test.

\section{Field sampling}

In total, 104 samples of recently metamorphosed crabs (54 Cy. angulatus, 48 Ch. granulata) were taken from October 1992 to December 1995. The frequency of collection was two or three times a month in summer and less frequently in winter. $C y$. angulatus recruits were collected from ten core samples $(300 \mathrm{ml})$ extracted from Ficopomatus enigmaticus "reefs". Ch. granulata were obtained by hand in an area with a high density of adult burrows and a variable number of sample units $\left(0.25 \mathrm{~cm}^{2}\right)$, selected at random along a transect. In all individuals, CW was measured.

A size frequency distribution (SFD) was constructed for each sample, with the following size intervals $(\mathrm{CW})$ : size class 1-4 mm: intervals of $0.25 \mathrm{~mm}$; 4.01-8 $\mathrm{mm}$ : $0.5 \mathrm{~mm}$; 8.01-11 mm: $1 \mathrm{~mm}$. For species with a short but intense recruitment period and with low intracohort variability in growth, several graphical and statistical methods have been developed to estimate growth rates from the displacement of modal SFD classes (Hartnoll 1978, 1982, 1983; Klein Breteler 1975; Orensanz and Gallucci 1988).
The two species studied here, however, show a long recruitment period with several pulses of reproductive activity, as well as intracohort variability in growth, due to small-scale and short-term heterogeneneity in the environmental conditions (Luppi 1999). Consequently, the available analytical methods could not be used in this study. The displacement of modal classes was thus determined visually, and linear least-square regressions of modal values and time elapsed from the first appearance of the putative cohorts were calculated. The slopes of regression lines obtained in the field and laboratory were compared using an ANCOVA (Zar 1984).

\section{Field experiments}

Megalopae of Cy. angulatus and Ch. granulata were collected in Mar Chiquita in February 1997 and 1998, transported to the laboratory and reared through metamorphosis as previously described. Groups of $20 \mathrm{Cy}$. angulatus in the $\mathrm{C} 1$ instar were placed in 31 plastic containers with perforated walls and lids, covered with a plastic screen (500 $\mu \mathrm{m}$ mesh size). A piece of polychaete "reef" (approximately $500 \mathrm{ml}$, without crabs) was placed as refuge. Five replicates were suspended from a rope and submerged in the lagoon $(30 \mathrm{~cm}$ above the bottom). After 30 days, the survivors were collected, counted, and measured $(\mathrm{CW})$.

Groups of $20 \mathrm{Ch}$. granulata in the $\mathrm{C} 1$ instar were placed in each of four 101 tubes with perforated walls and top, covered with a plastic screen $(500 \mu \mathrm{m}$ mesh size). These tubes were buried $15 \mathrm{~cm}$ deep in the substrate near adult burrows, after the removal of naturally occurring juvenile crabs. The numbers and $\mathrm{CW}$ of the survivors were recorded after 21 days. Differences in mean size among replicates were evaluated with a one-way ANOVA followed by Student-Neuman-Keuls test or with a Kruskal-Wallis test for median comparison in case of deviations from normality or homosedasticity.

\section{Results}

Laboratory growth and morphometric changes

\section{Cyrtograpsus angulatus}

Survival was high, with $93.5 \%$ of all individuals still alive after 105 days of rearing (Table 1). The crabs reached instar C9 and $13 \pm 0.6 \mathrm{~mm} \mathrm{CW}$ after 92 days (Fig. 2a). The intermolt period (IP) increased during juvenile growth, more rapidly after the $\mathrm{C} 4$ instar, from $5.8 \pm 1.4$ days $(\mathrm{C} 1-\mathrm{C} 2)$ to $34.3 \pm 6.2$ days $(\mathrm{C} 8-\mathrm{C} 9$; Fig. 2b). The percentage size increment (PSI) did not show a clear pattern, varying between $24 \%$ and $37 \%$ (Fig. 2c). All regressions of body size on instar number were significant. The slopes of the relationships between

Table 1 Survival (individual number and percentage) in successive crab instars of Cyrtograpsus angulatus and Chasmagnathus granulata. $n$ Number of individuals at the beginning of experiment

\begin{tabular}{llllllllll}
\hline \multirow{2}{*}{ Species } & \multicolumn{1}{l}{ Instar } & 110 & & & & & & \\
\cline { 2 - 10 } & $n$ & 1 & 2 & 3 & 4 & 5 & 6 & 7 & 8 \\
\hline Cyrtograpsus & 30 & 30 & 30 & 30 & 28 & 28 & 28 & 28 & 28 \\
angulatus & $(\%)$ & 100 & 100 & 100 & 93 & 93 & 93 & 93 & 93 \\
Chasmagnathus & 30 & 29 & 28 & 28 & 26 & 26 & 25 & 25 & - \\
granulata & $(\%)$ & 97 & 93 & 93 & 87 & 87 & 83 & 83 & - \\
\hline
\end{tabular}



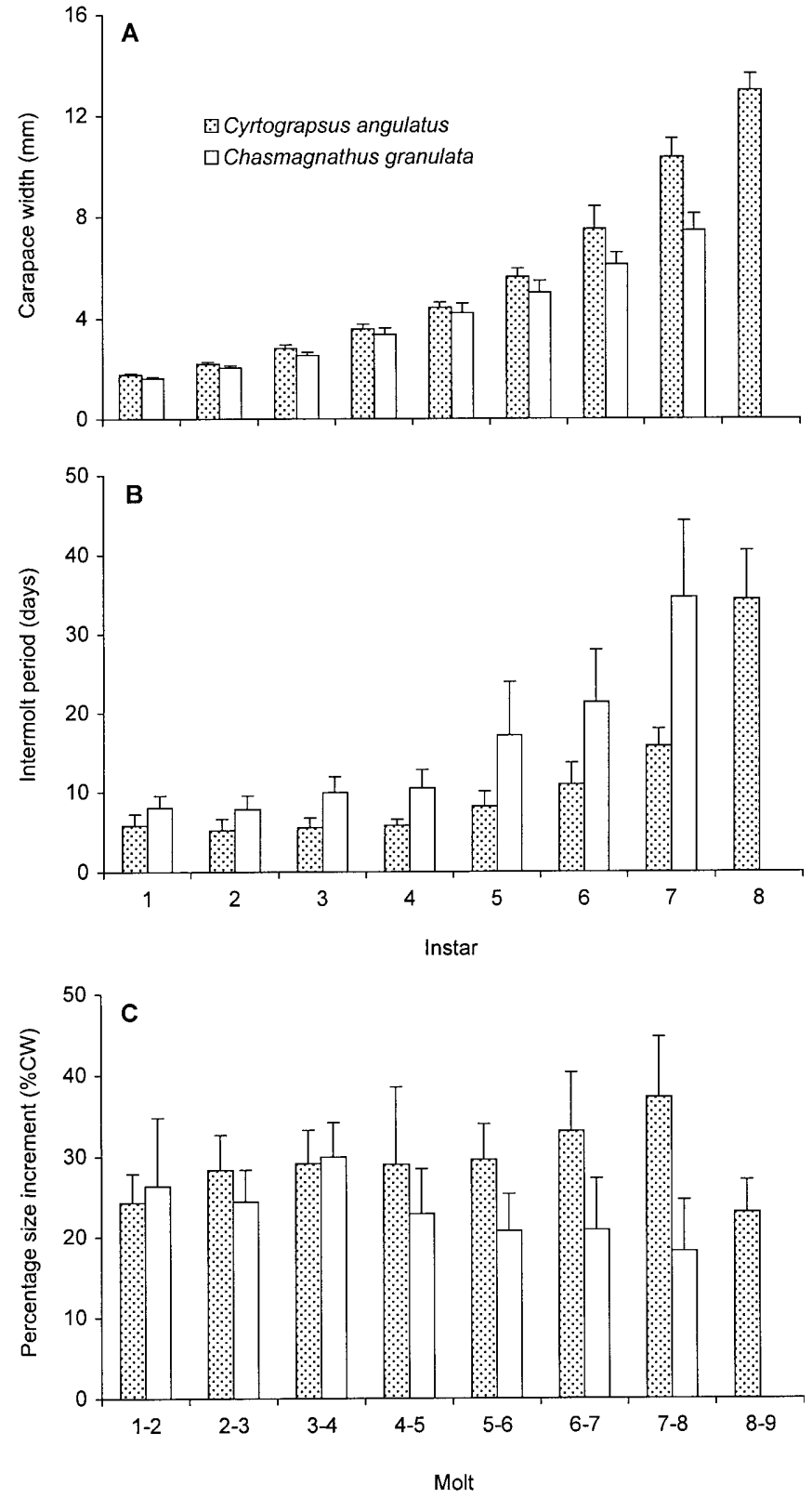

Fig. 2A-C Growth of Cyrtograpsus angulatus and Chasmagnathus granulata through successive juvenile instars. A Carapace width $C W, \mathbf{B}$ intermolt period $I P, \mathbf{C}$ percentage size increment $P S I$, in successive molts (mean values $\pm \mathrm{SD}$ )

$\mathrm{CHH}, \mathrm{CHL}$ and PW regressed on the instar number differed significantly between sexes (Fig. 3a-e).

The RGI allowed for the examination of morphometric changes during the course of juvenile development, and hence, was able to detect those instars where sex-specific differences appeared. In the $\mathrm{C} 1$ instar, the carapace was longer than wide $(\mathrm{CW}<\mathrm{CL})$, but this relationship reversed in the $\mathrm{C} 2$ so that $\mathrm{CW}$ was larger than $\mathrm{CL}$ in all later instars. The CL/CW quotient, however, did not show a statistically significant difference between sexes in any instar (Fig. 4a). From the C4 instar stage, the chelae tended to become proportionally higher and longer in males than in females, and these sex-specific morphometric differences increased throughout juvenile development (Fig. 4b, c). From the C5 onward, the pleon was significantly wider in females than in males; this typical sex-specific character became increasingly conspicuous in the subsequent juvenile instars, with a stabilizing PW/CW relation reached by instar C9 (Fig. 4d).

Chasmagnathus granulata

After 120 days, 25 individuals (83\%) were still alive (Table 1). During this period, the crabs reached the C8 instar and an average $\mathrm{CW}$ of $7.4 \pm 0.6 \mathrm{~mm}$ (Fig. 2a). The IP increased from $8 \pm 1.5$ days (instars $\mathrm{C} 1-\mathrm{C} 2$ ) to 34.6 \pm 9.6 days (C7-C8; Fig. 2b). The PSI showed no clear tendency, varying between $18 \%$ and $30 \%$ (Fig. 2c). All regressions of the various measurements of body size and the instar number were statistically highly significant (Fig. 3). Significant sex-specific differences between the slopes of these regression lines were observed in $\mathrm{CW}, \mathrm{CL}, \mathrm{CHH}$ and $\mathrm{CHL}$ (Fig. $3 \mathrm{f}-\mathrm{j}$ ). In the $\mathrm{C} 1$ instar, carapace length and width were almost identical $(\mathrm{CL} / \mathrm{CW}=1)$, but as $\mathrm{CW}$ grew proportionally faster in the subsequent instars, the CL/CW index decreased thereafter, stabilizing from $\mathrm{C} 5$; it did not differ significantly between males and females in any instar (Fig. 4e). From the $\mathrm{C} 3$ or $\mathrm{C} 4$ instar, respectively, the chela was significantly higher and wider in males than in females; these sex-specific morphometric differences increased in later juvenile instars (Fig. 4f, g). The pleon width in relation to $\mathrm{CW}$ did not differ significantly between sexes; thus, this sex-specific character develops in Ch. granulata only after the C8 instar (Fig. 4h).

Data from field-collected crabs allowed us also to study the relative growth patterns in later juvenile instars (5). In Cy. angulatus, the CL/CW quotient had a virtually constant value in the size range between 15 and $40 \mathrm{~mm} \mathrm{CW}$. It was $7.7 \%$ higher than the value observed in the largest laboratory-reared crabs (C9 instar, $13 \mathrm{~mm}$ $\mathrm{CW})$. On the other hand, Ch. granulata had already reached the same $\mathrm{CL} / \mathrm{CW}$ value as in larger field-collected crabs by the C8 instar stage (Fig. 4a, e). The sexspecific differences in relative chela width and height continued to increase in larger crabs, although these morphometric changes also differed between the two species. In large female $C y$. angulatus, the size proportions of the chelae were similar to those observed in laboratory-reared C9 crabs, while the relative chela size of the males continued to increase throughout later growth (Fig. 4b, c). In Ch. granulata, chela size in relation to CW continued to increase in both sexes, but this proportional increase was greater in males, so that the sex-specific differences tended to increase from juvenile to adult crabs (Fig. 4f, g). In both species, the pleon shape did not change after the C9 instar in males, while the $\mathrm{PW} / \mathrm{CW}$ relation of female crabs increased until a $\mathrm{CW}$ of about $20 \mathrm{~mm}$ was reached, remaining constant only thereafter (Fig. 4d, h). 
Fig. 3 Cyrtograpsus angulatus (A-E), Chasmagnathus granulata $(\mathbf{F}-\mathbf{J})$ : least-square regression lines and equations describing changes in various body dimensions (measured in $\mathrm{mm}$; logarithmic scale) as functions of the juvenile instar number; underlined equations males, not underlined females, $R^{2}$ coefficient of determination, $N$ number of individuals, $F$ statistic for slope comparisons, $P$ level of significance for differences between slopes, $C W$ carapace width, $C L$ carapace length, $\mathrm{CHH}$ chela height, $C H L$ chela length, $P W$ pleon width
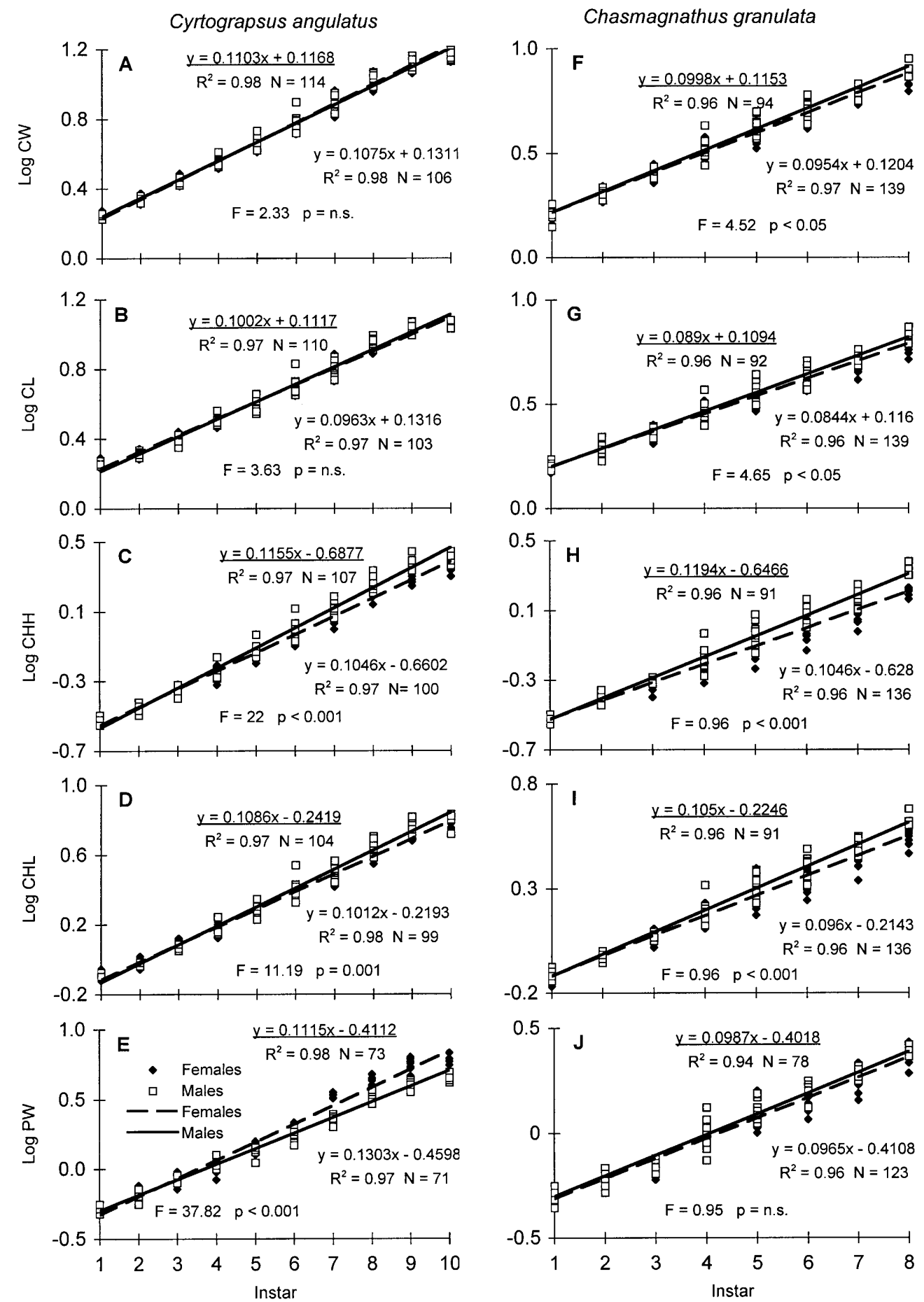

Instar duration was significantly affected by rearing temperatures in both species. In the $\mathrm{C} 1$ instar of $C y$. angulatus, the IP was four times shorter at $21^{\circ} \mathrm{C}$ than at $12^{\circ} \mathrm{C}$. During the time of the experiment, juveniles reached the $\mathrm{C} 4$ instar at $21^{\circ} \mathrm{C}$, but at $12^{\circ} \mathrm{C}$ only the $\mathrm{C} 2$ was reached. On the other hand, $\mathrm{C} 1$ reared at $12^{\circ} \mathrm{C}$ were significantly larger than those reared at $21^{\circ} \mathrm{C}(T=210$, $P<0.05$, Table 2) and also larger than those collected in the field ( $T=4,713, P<0.0001$, Fig. $6 a)$. Ch. granulata juveniles generally grew more slowly than $C y$. angulatus in the laboratory; at $21^{\circ} \mathrm{C}$, they reached the $\mathrm{C} 3$ instar after 30 days, whereas no molts occurred at $12^{\circ} \mathrm{C}$.

Growth in the field

\section{Size frequency distributions}

Only juvenile $C y$. angulatus with $\mathrm{CW}<7 \mathrm{~mm}$ were found in F. enigmaticus "reefs". Their size frequency 
Fig. 4 Cyrtograpsus angulatus (A-D), Chasmagnathus granulata $(\mathbf{E}-\mathbf{H})$ : changes in relative growth indices $R G I$ (quotients of various body dimensions and carapace width $C W$, mean values \pm SD) during juvenile growth through successive instars in laboratory cultures; *** $P<0.01$, ** $P<0.05$ (comparisons between males and females; Mann-Whitney median tests); $C L$ carapace length, $\mathrm{CHH}$ chela height, $\mathrm{CHL}$ chela length, $P W$ pleon width
Table 2 Instar reached, duration, and size of the $\mathrm{C} 1$ instar of Cyrtograpsus angulatus and Chasmagnathus granulata reared in the laboratory at $21^{\circ} \mathrm{C}$ and $12^{\circ} \mathrm{C}($ mean $\pm \mathrm{SD})$
Cyrtograpsus angulatus
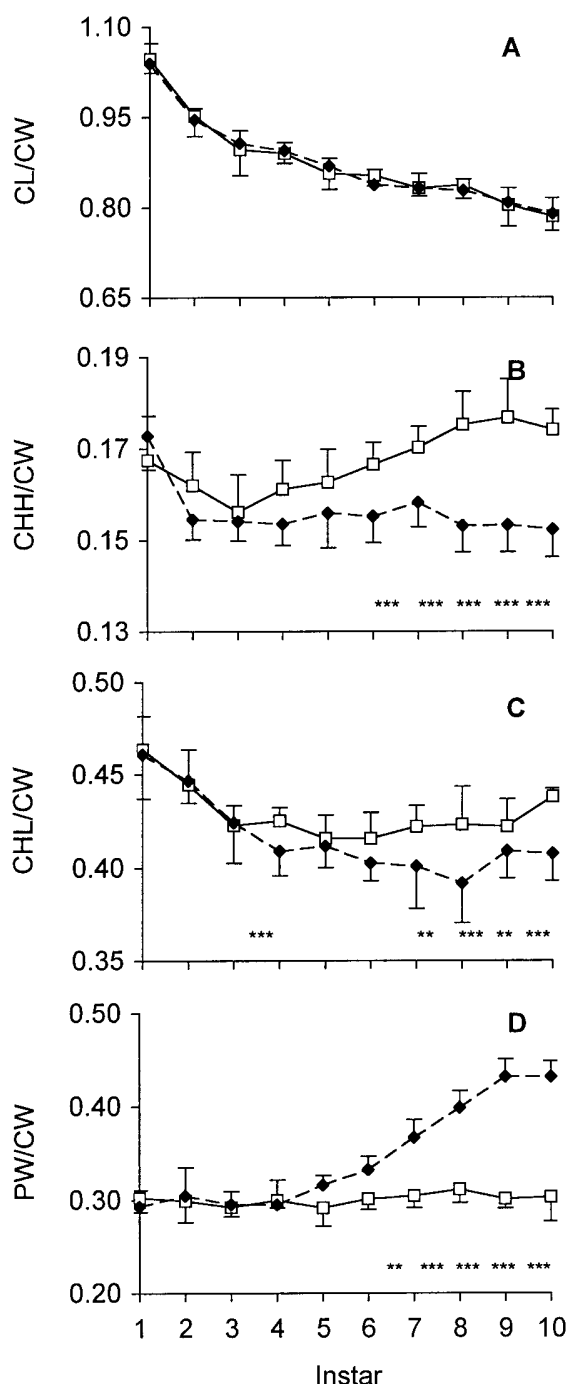

Chasmagnathus granulata
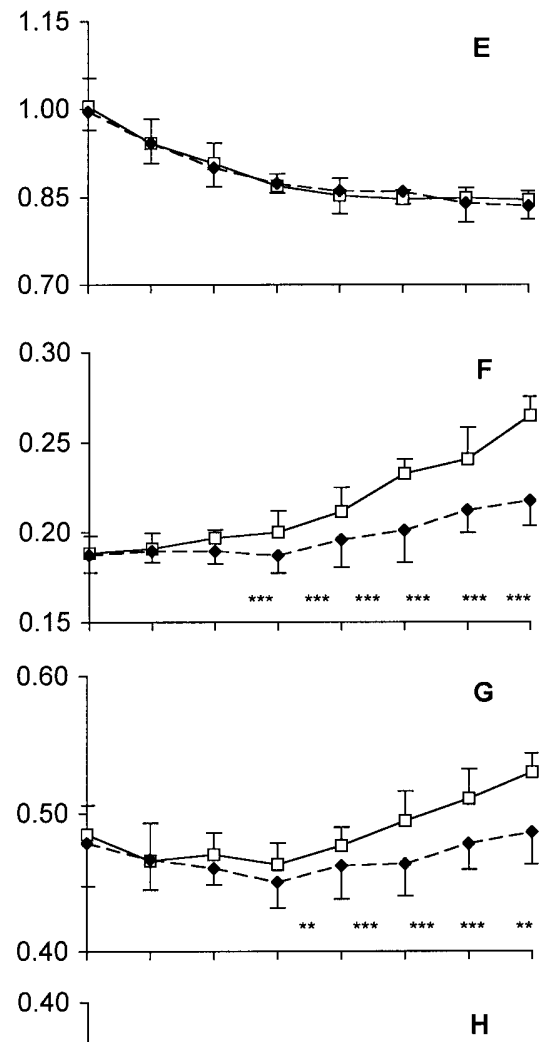

H

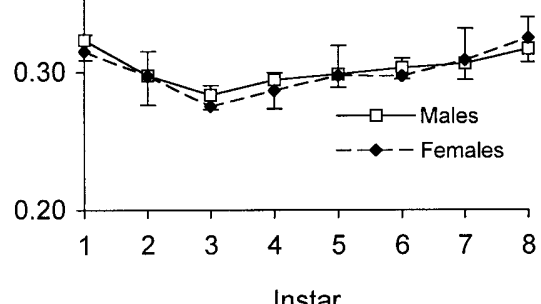

\begin{tabular}{llll}
\hline Temperature $\left({ }^{\circ} \mathrm{C}\right)$ & Instar & Duration of C1 (days) & Size (mm) of C1 \\
\hline Cyrtograpsus angulatus & & & \\
21 & 4 & $7.1 \pm 0.9$ & $1.64 \pm 0.05$ \\
12 & 2 & $28 \pm 4.4$ & $1.71 \pm 0.08$ \\
Chasmagnathus granulata & & & \\
21 & 3 & $10.9 \pm 2$ & $1.51 \pm 0.05$ \\
12 & 1 & - & - \\
\hline
\end{tabular}

distributions (SFDs) indicated a continuous recruitment throughout the summer and most of autumn, generally with the highest intensity in early summer and several smaller peaks thereafter (Fig. 6a). No conspicuous changes occurred during winter. In the spring, the SDFs were generally displaced towards larger size classes, indicating resumed growth, while a decreasing number of individuals indicated emigration or mortality. No single cohorts could safely be identified in this species and, consequently, the growth of Cy. angulatus in the field could not be estimated from SFDs.
In Ch. granulata, the analysis of SFDs permitted the identification of several summer recruitment periods throughout a 39 month sampling period: two in 1993, four in 1994 and three in 1995 (Fig. 6b). In January 1995, two successive recruitment periods were observed. Five cohorts could be identified, from which growth was estimated according to the displacement of modal size classes (Fig. 7). Daily growth rates varied between 0.043 and $0.067 \mathrm{~mm} /$ day (recruitment detected on 29 December 1992 and 15 January 1995, respectively), yielding an average value of $0.056 \mathrm{~mm} /$ day for the pooled data 
Fig. 5 Cyrtograpsus angulatus (A-D), Chasmagnathus granulata $(\mathbf{E}-\mathbf{H})$ : changes in relative growth indices $(R G I)$ measured in the field (quotients of various body dimensions and carapace width, $C W$ mean values $\pm \mathrm{SD}$ ) in successive juvenile size classes (class means given in the X-axis; field-data); the first pair of columns is, for comparison, the RGI measured in the last crab instar reared in the laboratory; $C L$ carapace length, $\mathrm{CHH}$ chela height, $C H L$ chela length, $P W$ pleon width

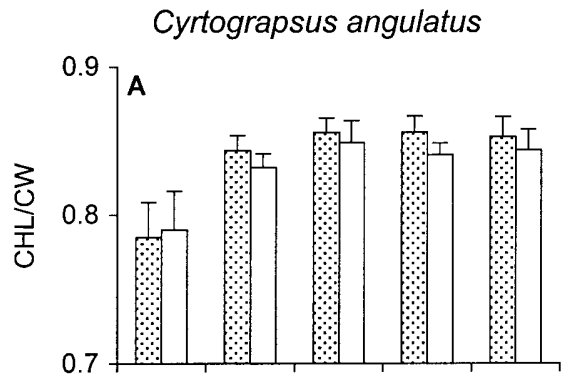

Chasmagnathus granulata
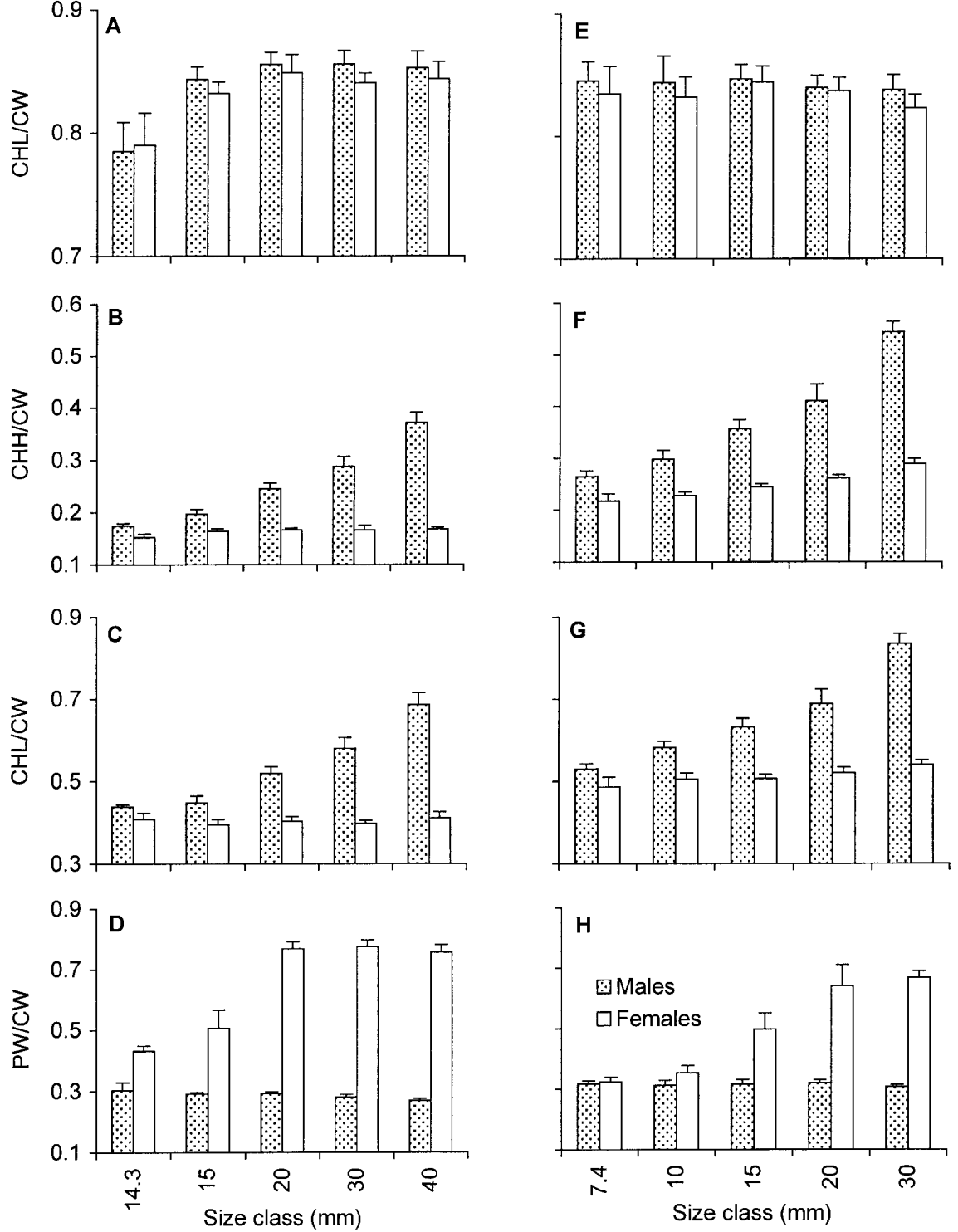

from all cohorts (Fig. 7). Crabs reared at $24^{\circ} \mathrm{C}$ in the laboratory grew $0.063 \mathrm{~mm} /$ day, which did not differ significantly from data estimated in the field (ANCOVA, $F=3.83, P>0.05)$.

\section{Field experiments}

$\mathrm{C} 1$ instar Cy. angulatus collected from the field measured $1.63 \pm 0.06 \mathrm{~mm} \mathrm{CW}$ (mean $\pm \mathrm{SD}$ ). The average air temperature during the field experiments was $18.8^{\circ} \mathrm{C}$. After 30 days, the number of survivors varied from 7 to 18 individuals among the replicates, and their size varied from 5.6 to $8.2 \mathrm{~mm} \mathrm{CW}$ (Table 3), differing significantly among replicates (ANOVA, $F=10.5, P<0.01$ ). Largest size and highest survival were observed in the same replicate experiment; smallest size and lowest survival coincided with the accidental presence of an adult Cyrtog- rapsus altimanus. In this experiment, the growth rate of Cy. angulatus varied from 0.13 to $0.22 \mathrm{~mm} / \mathrm{day}$; the size reached in the field was significantly larger than that observed during an equally long period in the laboratory ( $T=57,55,98,55,55$, respectively, for different replicates; $P<0.001$ ).

The size of the $\mathrm{C} 1$ instar of $C h$. granulata was $1.5 \pm 0.04 \mathrm{~mm} \mathrm{CW}$ in the field. The mean air temperature during the experiments with this species was $18.2^{\circ} \mathrm{C}$. The number of survivors after 30 days varied among replicates from eight to 26 individuals, and their size varied from 2.5 to $2.7 \mathrm{~mm} \mathrm{CW}$ (Table 3). In this species, size did not differ significantly among replicates $(H=2.98$, $P>0.1$ ). In a few replicates, the number of crabs was higher at the end of the experiment, due to the immigration of megalopae; the lowest number of crabs was observed in one replicate that had been invaded by larger juveniles. The average growth rate was $0.051 \mathrm{~mm} / \mathrm{day}$; 
Fig. 6 Cyrtograpsus angulatus (A), Chasmagnathus granulata (B): size-frequency distribution in Mar Chiquita lagoon; sampling date and number of individuals measured (in brackets)

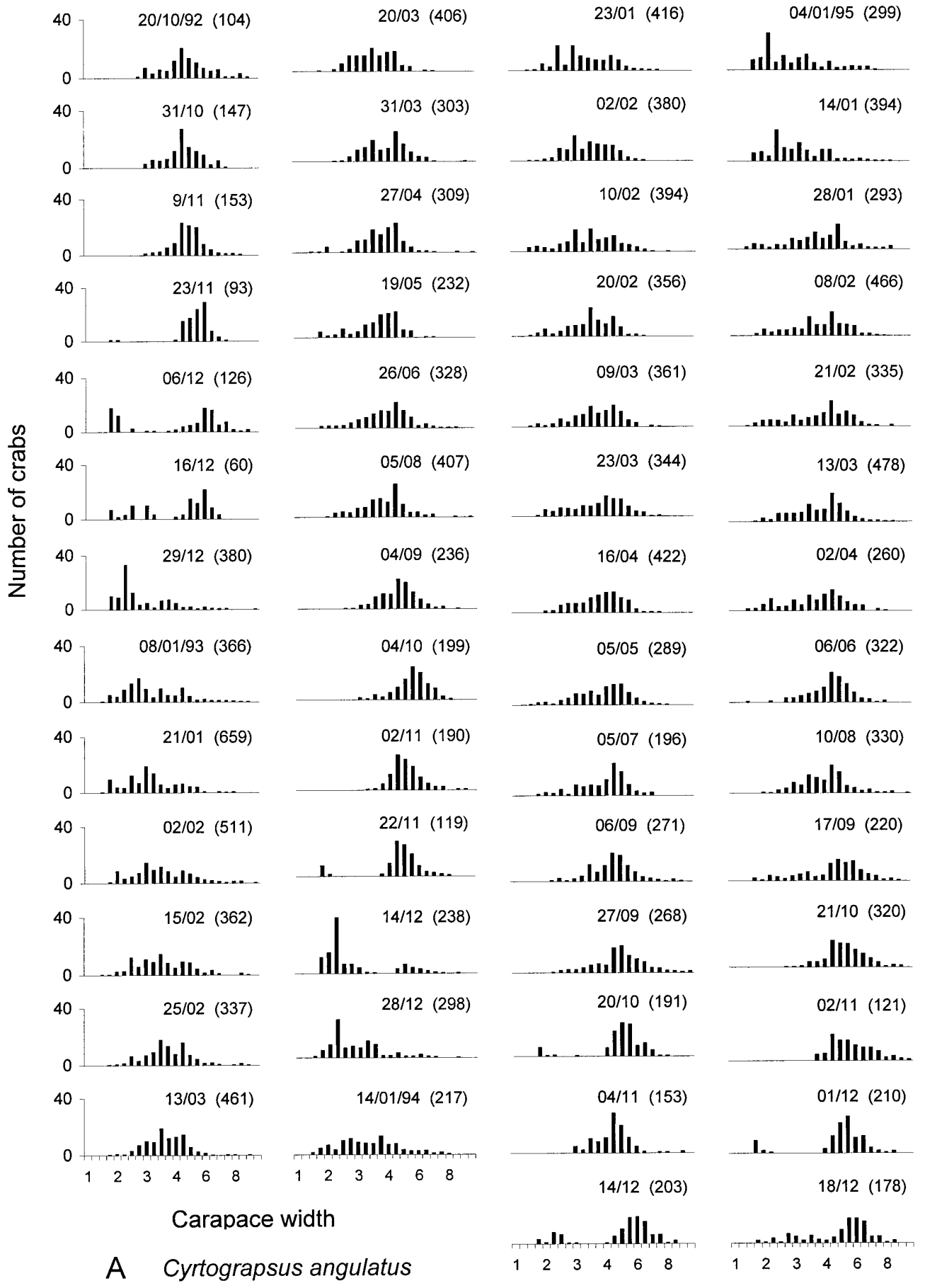

\section{A Cyrtograpsus angulatus}

Table 3 Carapace width (mean \pm standard deviation) and number of survivors (in brackets) in the field and laboratory, measured at the end of the field experiment (after 30 days in Cyrtograpsus angulatus and after 21 days in Chasmagnathus granulata); different letters indicate significant differences among replicates (*replicate experiment with invasion of adults or juveniles)

\begin{tabular}{|c|c|c|c|c|c|c|}
\hline \multirow[t]{2}{*}{ Species } & \multicolumn{5}{|c|}{ Size $(\mathrm{mm})$ and number of survivors in replicate field experiments } & \multirow{2}{*}{$\begin{array}{l}\text { Size }(\mathrm{mm}) \text { in the } \\
\text { laboratory }\end{array}$} \\
\hline & 1 & 2 & 3 & 4 & 5 & \\
\hline Cyrtograpsus angulatus & $\begin{array}{l}6.7 \pm 1 \\
(12) \\
a\end{array}$ & $\begin{array}{l}6.7 \pm 1.2 \\
(18) \\
\mathrm{a}\end{array}$ & $\begin{array}{l}5.6 \pm 1.1 \\
(7)^{*} \\
\text { b }\end{array}$ & $\begin{array}{l}7.8 \pm 1 \\
(15) \\
\mathrm{c}\end{array}$ & $\begin{array}{l}8.2 \pm 1 \\
(18) \\
\mathrm{c}\end{array}$ & $4.4 \pm 0.2$ \\
\hline Chasmagnathus granulata & $\begin{array}{l}2.5 \pm 0.3 \\
(26) \\
\mathrm{a}\end{array}$ & $\begin{array}{l}2.5 \pm 0.1 \\
(17) \\
\mathrm{a}\end{array}$ & $\begin{array}{l}2.6 \pm 0.3 \\
(26) \\
\mathrm{a}\end{array}$ & $\begin{array}{l}2.7 \pm 0.3 \\
(8)^{*} \\
\mathrm{a}\end{array}$ & - & $2.5 \pm 0.1$ \\
\hline
\end{tabular}




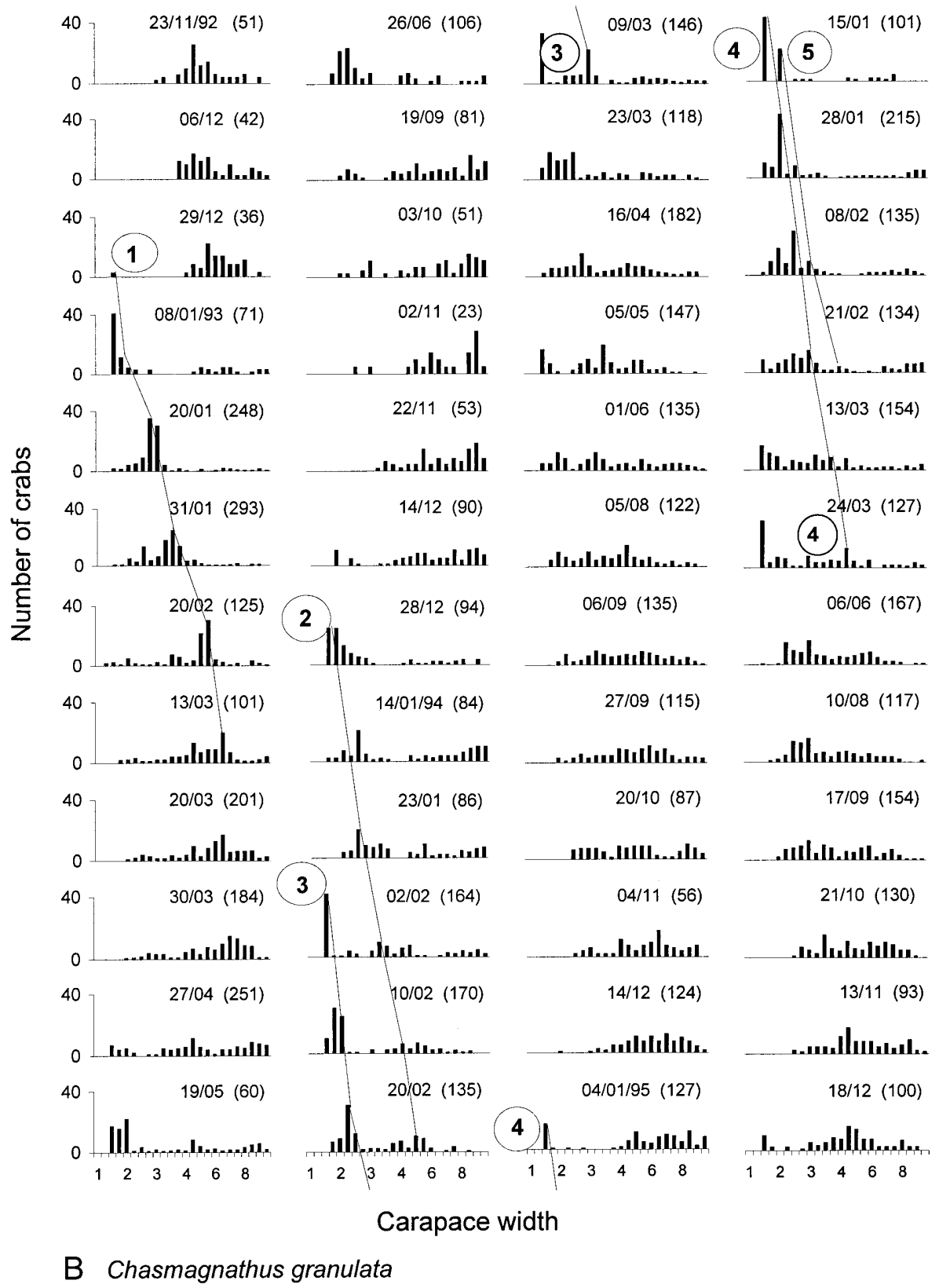

the size reached in the field did not differ significantly from that in the laboratory $(T=1,469, P>0.1)$.

\section{Discussion}

During the juvenile development of $C y$. angulatus and Ch. granulata, the intermolt period (IP) increased, especially after instar 4 , while the percentage size increment (PSI) tended to decrease. These patterns have commonly been observed in various crustaceans (e.g. Kurata 1962; Mauchline 1977; Hartnoll 1982; Mohamedeen and Hartnoll 1989; Tweedale et al. 1993). Compared with a previous study by Spivak (1988) on a marine population of Cy. angulatus, the PSI measured in this study, in the same species, was generally higher, while the IP was shorter. In individuals with $5 \mathrm{~mm} \mathrm{CW}$, for instance, the PSI observed in this study was $27 \%$ and the IP was 8 days, whereas Spivak estimated $22.4 \%$ and 17 days, respectively. The rearing conditions differed in these studies mainly in the type of food, while the temperatures were similar. Longer IP and lower PSI values were also reported for juvenile $C h$. granulata from Lagoa dos Patos (Brazil) reared at $20^{\circ} \mathrm{C}$ (Rieger and Nakagawa 1995). In this case, the lower temperature explains differences in the IP. However, strong differences were observed also in size: the first crab instar was $28 \%$ larger in Mar Chiquita $(\mathrm{CW}=1.61 \mathrm{~mm}$ in Mar Chiquita vs $1.26 \mathrm{~mm}$ in Lagoa dos Patos); this difference increased in later instars, in spite of similar rearing conditions, reaching $57 \%$ in the C8 instar. 
Fig. 7 Chasmagnathus granulata): growth of Chasmagnathus granulata according dates: 29 December 1992, 28 December 1993 , 2 February 1994, 4 January 1995, 15 January 1995; corresponding to presumable cohorts $1-5$ as identified from Fig. 6b), in field experiments (field exp), and in laboratory experiments (lab) to field samples (sampling

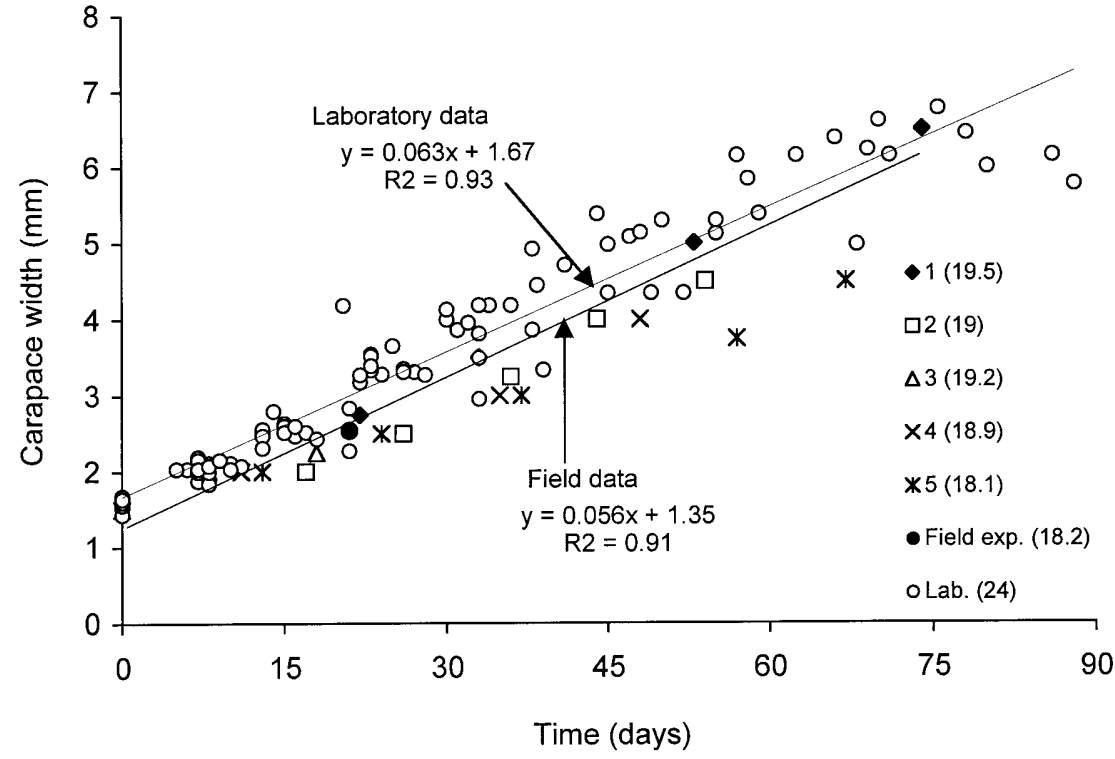

The carapace shape changes in both species during the development through the first juvenile instars; in the megalopae, it is notably longer than wide, especially in Cy. angulatus, while the opposite relation is typical of the adults. Rieger and Nakagawa (1995) and Gebauer et al. (1999) reported similar relationships between LC and $\mathrm{CW}$ for $\mathrm{Ch}$. granulata.

The morphological traits of the chelae and of the pleon are considered as secondary sexual characters in the Brachyura (Hartnoll 1982; Yatsuzuka and Meruane 1987; Abelló et al. 1990; Minagawa 1993). Variations in the relative growth of these body parts are associated with different functions in reproduction. The larger male chelipeds are used in courtship, combat and carrying the female during copula; they show a higher proportional growth in relation to total body size (Hartnoll 1982; Minagawa 1993). The reverse was found in the pleon, which shows a faster relative growth in females, where it forms the incubatory chamber for developing eggs, while the male pleon protects and supports the intromittent organs (Hartnoll 1982; Minagawa 1993).

In both species, the chelae begin to show differences between the sexes early in development. This process of sexual differentiation starts earlier and is more intense in Ch. granulata than in Cy. angulatus. Chela dimorphism in Decapoda is frequently associated with sexual selection and mating systems (Orensanz and Gallucci 1988). It was suggested that the mating system is characterized by resource (burrow) defense in Ch. granulata and by female defense or male dominance in Cy. angulatus (Gavio and Spivak 1994). An early acquisition of chelar dimorphism in Ch. granulata could thus be associated with the building and defense of burrows, where mating usually takes place (T.A. Luppi, personal observation). The suggested mating system of $C y$. angulatus is characterized by a less well developed sexual dimorphism of the chelae (Orensanz and Gallucci 1994).
The pleon differentiates early in Cy. angulatus females; in Ch. granulata, in contrast, it is impossible to recognize the sex before the $\mathrm{C} 9$ instar. The growth increment per molt is lower in Ch. granulata than in Cy. angulatus (Figs. 2 and 5). Since the females of both species mature at similar sizes (T.A. Luppi, unpublished data), there should be differences in the number of molts needed to reach maturity.

Sexual maturity in crabs occurs after a "puberty" molt, when morphological changes can be recognized by changes in the slopes of regressions describing relative growth. The immature phase of the crab life cycle includes an "undifferentiated period", which is characterized by the lack of variation in allometric growth of those organs that both sexes have in common, followed by a "juvenile period" with sexual differences in relative growth, and these periods may be separated by a particular molt (Hartnoll 1982). In the species studied here, however, sexual differences in various structures became evident in different instars (Fig. 4).

Low temperature increases the IP in Cy. angulatus, as has been reported for many species of crustaceans (e.g. Tagatz 1968; Leffler 1972; Chittleborough 1975; Hartnoll 1982; Cadman and Weinstein 1988; Tunberg and Creswell 1991), and it appears to cause the attainment of a larger body size, as also observed in other crabs (Leffler 1972; Chittleborough 1975; Hartnoll 1982). Daily changes in water temperature (ranging in summer between 15 and $34^{\circ} \mathrm{C}$ ) may thus explain also the larger range of variability in the size of the $\mathrm{C} 1$ instar in the field (25\% of the mean) as compared with that observed under constant laboratory conditions (10\%). Effects of physical factors (temperature, salinity), interacting with those of diet, were also suggested as an explanation for size variability in $\mathrm{C} 1$ Cancer magister (DeBrosse et al. 1990; Dinnel et al. 1993). On the other hand, a 5th zoea appeared in Ch. granulata under extreme environmental conditions (starvation, low salinity; 
see Pestana and Ostrensky 1995), and C1 juveniles originating from this alternative developmental pattern tended to be larger (Gimenez 2000).

The SFDs of both species were characterized by a period of evident modal size displacement from October to May and a period without changes in winter. The latter should be a consequence of a reduced growth due to low temperatures (Fig. 1). Moreover, a marked decrease in juvenile activity occurs in the field during winter (T.A. Luppi, personal observation). Likewise, growth decreased or ceased in Callinectes sapidus and Cancer magister below critical temperatures in winter (Tagatz 1968; Leffler 1972; Orensanz and Gallucci 1988; McMillan et al. 1995).

The growth rates of Ch. granulata in the field, as estimated from the displacement of modal size classes, and those in laboratory cultures were similar, in spite of marked differences in the thermal regime. Among several cohorts, however, the size reached after a similar time span differed by up to $33 \%$, which may be explained by combined effects of temperature and salinity variations. These environmental factors were also shown to affect juvenile growth in Menippe mercenaria (Brown et al. 1992).

In our study, $C y$. angulatus generally grew faster in field enclosures than in laboratory cultures, as found also in Ca. magister (Collier 1983). On the other hand, the crabs in different parallel experiments (replicates) exhibited different sizes (Table 3), probably as a consequence of microscale differences in temperature which may reach about $4{ }^{\circ} \mathrm{C}$ in Mar Chiquita lagoon (see Anger et al. 1994). Similarly, growth differs between early and late cohorts, due to marked seasonal temperature differences. A megalopa settling in early summer (December) should live for about 30 days within the polychete "reef", where it is prone to intra- and interspecific predation by larger crabs (Luppi 1999). After this initial period, the juveniles leave this nursery habitat and migrate to open sediment areas. The surviving recruits may become sexually mature before the end of recruitment period. However, ovigerous females were seldom observed in late summer or autumn, suggesting that Cy. angulatus normally produces its first offspring at the beginning of the following spring season (Spivak et al. 1996). Megalopae that settle only in late summer (March), by contrast, should remain in the "reef" habitat, until they resume their growth the next spring. Crabs from the latest cohort may not reach maturity until the end of the following summer.

In one of the field experiments, high mortality occurred in Cy. angulatus (but not in Ch. granulata), presumably caused by cannibalism or predation by invading juvenile or adult crabs, and coinciding with a particularly small recruit size in this species. In recruits of Carcinus maenas, reduced growth and feeding activity were also observed when larger conspecific crabs were present (Adelung 1971; Klein Breteler 1975). In Ch. granulata, in contrast, recruits and adults were observed to coexist in the natural habitat, showing apparently low pressure of cannibalism (Luppi 1999).
Acknowledgements This investigation was part of a bilateral cooperation program (MAR-8) between the Universidad Nacional de Mar del Plata (UNMDP), Argentina, and the Biologische Anstalt Helgoland, Germany. It was funded with UNMdP (15/E082, 15/E149) and Consejo Nacional de Investigaciones Científicas y Técnicas de Argentina (CONICET; PIP 838/98) grants to E.S., with UNMdP and CONICET fellowships to T.L., by the Secretaría de Ciencia y Tecnología (Argentina) and, on behalf of the German Federal Ministry of Education, Science and Technology, by the International Bureaus of the Alfred-WegnerInstitut für Polar- und Meeresforschung (Bremerhaven, Germany) and the Forschungszentrum Jülich GmbH (Jülich, Germany). This paper represents a part of the $\mathrm{PhD}$ thesis of T.L. We are grateful to C. Bas and R. Zenuto for their assistance in the field and laboratory.

\section{References}

Abelló P, Pertierra JP, Reid D (1990) Sexual size dimorphism, relative growth and handedness in Liocarcinus depurator and Macropipus tuberculatus (Brachyura: Portunidae). Sci Mar 54:195-202

Adelung D (1971) Untersuchungen zur Hautungsphysiologie der Decapoden Krebse am Beispiel der Strankrabbe Carcinus maenas. Helgol Meeresunters 22:66-119

Anderson W, Ford R (1976) Early development, growth and survival of the yellow crab Cancer anthoyi Rathbun (Decapoda, Brachyura) in the laboratory. Aquaculture 7:267-279

Anger K, Ismael D (1997) Growth and elemental composition $(\mathrm{C}, \mathrm{N}, \mathrm{H})$ in larvae and early juveniles of a South American salt marsh crab, Chasmagnathus granulata (Decapoda: Grapsidae). Mangroves Salt Marshes 1:219-227

Anger K, Bas C, Spivak ED, Ismael D, Luppi TA (1994) Hatching rhythms and dispersion of decapod crustacean larvae in a brackish coastal lagoon in Argentina. Helgol Meeresunters 48:445-466

Boschi EE (1964) Los crustáceos decápodos Brachyura del litoral bonaerense (R Argentina). Bol Inst Biol Mar Mar del Plata 6:1-99

Boschi EE (1988) El ecosistema estuarial del Río de la Plata (Argentina y Uruguay). An Inst U N A M Ser Cienc Mar Limnol 15:159-182

Boschi EE, Scelzo MA, Goldstein B (1967) Desarrollo larval de dos especies de Crustaceos Decapodos en el laboratorio Pachycheles haigae Rodriguez Da Costa (Porcellanidae) y Chasmagnathus granulata Dana (Grapsidae). Bol Inst Biol Mar Mar del Plata 12

Brown SD, Bert TM, Tweedale WA, Torres JJ, Lindberg WJ (1992) The effects of temperature and salinity on survival and development of early life stage Florida stone crabs Menippe mercenaria (Say). J Exp Mar Biol Ecol 157:115136

Cadman LR, Weinstein MP (1988) Effects of temperature and salinity on the growth of laboratory-reared juvenile blue crabs Callinectes sapidus Rathbun. J Exp Mar Biol Ecol 121:193207

Chittleborough RG (1975) Environmental factors affecting growth and survival of juvenile western rock lobsters Panulirus longipes (Milne-Edwards). Aust J Mar Freshw Res 26:177-196

Collier PC (1983) Movement and growth of post-larval Dungeness crabs, Cancer magister, in the San Francisco area. Fish Bull Calif Dept Fish Game 172:85-96

Dinnel P, Armstrong D, McMillan R (1993) Evidence for multiple recruitment-cohorts of Puget sound Dungeness crab, Cancer magister. Mar Biol 115:53-63

DeBrosse G, Sulkin S, Jamieson G (1990) Intraspecific morphological variability in megalopae of three sympatric species of the genus Cancer (Brachyura: Cancridae). J Crustac Biol $10: 315-329$ 
Gavio A, Spivak ED (1994) Uso del hábitat, crecimiento relativo y dimorfismo sexual en dos especies simpátricas de Cyrtograpsus. Resumen II Taller sobre cangrejos y cangrejales, Mar del Plata, Argentina

Gebauer P, Walter I, Anger K (1998) Effect of substratum and conspecific adults on the metamorphosis of Chasmagnathus granulata (Dana) (Decapoda: Grapsidae) megalopae. J Exp Mar Biol Ecol 223:185-198

Gebauer P, Paschke K, Anger K (1999) Costs of delayed metamorphosis: reduced growth and survival in early juveniles of an estuarine grapsid crab, Chasmagnathus granulata. J Exp Mar Biol Ecol 238:271-281

Giménez L (2000) El efecto de la salinidad y la biomasa inicial en el desarrollo larval del cangrejo estuarino Chasmagnathus granulata (Crustacea, Decapoda). PhD thesis, Facultad de Ciencias, Universidad de la República, Montevideo, Uruguay

Hartnoll RG (1978) The effect of salinity and temperature on the post-larval growth of the crab Rhithropanopeus harrisi. In: McLusky DS, Berry AJ (eds) Physiology and behaviour of marine organisms. Pergamon, Oxford, pp 349-358

Hartnoll RG, (1982) Growth. In: Abele LG (ed) Embryology, morphology and genetics: the biology of crustacea, vol 2. Academic Press, New York, pp 111-196

Hartnoll RG (1983) Strategies of crustacean growth. Aust Mus Mem 18:121-131

Hebling NJ, Fransozo A, Negreiros-Fransozo ML (1982) Desenvolvimento dos primeiros estágios juvenis de Panopeus herbstii H Milne-Edwards, 1834 (Crustacea, Decapoda, Xanthidae), criados em laboratório. Nat Sao Paulo 7:177-188

Iribarne O, Bortolus A, Botto F (1997) Between-habitat differences in burrow characteristics and trophic modes in the southwestern Atlantic burrowing crab Chasmagnathus granulata. Mar Ecol Prog Ser 155:137-145

Ismael D, Anger K, Moreira G (1997) Influence of temperature on larval survival, development and respiration in Chasmagnathus granulata (Crustacea Decapoda). Helgol Meeresunters 51:463-475

Jones M, Simons M (1982) Habitats preferences of two estuarine burrowing crabs Helice crassa Dana (Grapsidae) and Macrophtalmus hirtipes (Jaquinot) (Ocypodidae). J Exp Mar Biol Ecol 56:49-62

Klein Breteler WC (1975) Growth and moulting of juvenile shore crabs, Carcinus maenas, in a natural population. Neth J Sea Res 9:86-99

Kurata H (1962) Studies on the age and growth of Crustacea. Bull Hokkaido Reg Fish Res Lab 24:1-115

Leffler CW (1972) Some effects of temperature on the growth and metabolic rate of juvenile blue crabs, Callinectes sapidus, in the laboratory. Mar Biol 14:104-110

Lopez LA, Rodriguez EM (1998) Somatic growth in juveniles of the estuarine crab Chasmagnathus granulata Dana 1851 (Brachyura, Grapsidae), under laboratory conditions. Invest Mar Valparaiso 26:127-135

Lopez Greco LA, Rodriguez, EM (1998) Size at the onset of sexual maturity in Chasmagnathus granulata Dana 1851 (Grapsidae, Sesarminae): a critical overall view about the usual criteria for its determination. In: Schram FR, Vaupel Klein JC von (eds) Crustaceans and the biodiversity crisis. Brill, Leiden, pp 675-689

Luppi TA (1999) La coexistencia de dos especies de cangrejo en el ecosistema del cangrejal: estudio comparativo del asentamiento y el reclutamiento (The coexistence of two crab species in the "cangrejal" ecosystem: comparative study of settlement and recruitment). Doctoral Thesis, Mar del Plata University, Argentina

Luppi TA, Spivak ED (1996) Autotomía de apéndices en el cangrejo estuarial Chasmagnathus granulata Dana, 1851 (Brachyura: Grapsidae) en la Laguna Mar Chiquita, Buenos Aires, Argentina. Atlantica 18:55-68

Luppi TA, Spivak ED, Anger K (1994) La coexistencia de dos especies de cangrejo en el ecosistema del cangrejal: estudio comparativo del asentamiento y el reclutamiento. Resumen II Taller sobre cangrejos y cangrejales, Mar del Plata, Argentina
Luppi TA, Bas CC, Spivak ED, Anger K (1997) Fecundity of two grapsid crab species in the Laguna Mar Chiquita, Argentina. Arch Fish Mar Res 45:149-166

Marcovecchio J, Marco S de, Pozzobon V, Gavio A, Asteasuain R, Rusansky C, Ferrer L, Andrade S, Freije H (1997) The role of estuaries as buffer zones to the littoral marine environment: the case of Mar Chiquita coastal lagoon, in Argentina. Resumen VII Congresso Latino-Americano sobre Ciencias do Mar, Santos, Brasil

Martos P, Reta R (1997) Aspectos hidrográficos de la región estuarial de la laguna de Mar Chiquita, Pcia de Buenos Aires. Resumen II Congreso Argentino de Limnología, Buenos Aires, Argentina, pp 18-24

Mauchline J (1977) Growth of shrimps, crabs and lobster - an assessment. J Cons Int Explor Mer 37:162-169

McMillan R, Armstrong D, Dinnel R (1995) Comparison of intertidal habitat use and growth rates of two northern Puget sound cohorts of 0+ age Dungeness crab, Cancer magister. Estuaries $18: 390-398$

Minagawa M (1993) Relative growth and sexual dimorphism in the red frog crab Ranina ranina (Decapoda: Raninidae). Nippon Suisan Gakkaishi 59:2025-2030

Mohamedeen H, Hartnoll RG (1989) Larval and postlarval growth of individually reared specimens of the common shore crab Carcinus maenas (L.). J Exp Mar Biol Ecol 134:1-24

Negreiros-Fransozo ML, Fransozo A (1991) Growth and age determination of three juvenile crab species (Crustacea, Decapoda, Brachyura). Papéis Avulsos Zool 37:277-283

O'Connor NJ (1990) Morphological differentiation and molting of juvenile fiddler crabs (Uca pugilator and $U$. pugnax). J Crustac Biol 10:608-612

Olivier S, Escofet A, Penchaszadeh P, Orensanz J (1972) Estudios ecológicos de la región estuarial de Mar Chiquita (Bs. As. Argentina). I. Las comunidades bentónicas. An Soc Cient Argent 193:237-262

Orensanz JM, Gallucci V (1988) Comparative study of postlarval life-history schedules in four sympatric species of Cancer (Decapoda: Brachyura: Cancridae). J Crustac Biol 8:187-220

Pestana D, Ostrensky A (1995) Occurrence of an alternative pathway in the larval development of the crab Chasmagnathus granulata Dana, 1851 under laboratory conditions. Hydrobiologia 306:33-40

Pillay K, Ono Y (1978) The breeding cycles of two species of grapsid crabs (Crustacea Decapoda) from the north coast of Kyushu, Japan. Mar Biol 45:237-248

Restrepo VR (1989) Growth estimates for male stone crabs along the southwest coast of Florida: a synthesis of available data and methods. Trans Am Fish Soc 118:20-29

Reta R, Martos P, Piccolo MC, Perillo GM, Ferrante A (1997) Características de la marea en la laguna costera Mar Chiquita, Argentina. Resumen. VII Congresso Latino-Americano sobre Ciencias do Mar, Santos, Brasil

Rieger PJ, Nakagawa C (1995) Desenvolvimiento juvenil de Chasmagnathus granulata Dana, 1851 (Crustacea, Decapoda, Grapsidae), em laboratorio. Nauplius 3:59-74

Seiple W (1979) Distribution, habitat preference and breeding periods in the crustaceans Sesarma cinereum and Sesarma reticulatum. Mar Biol 52:77-86

Seiple W, Salmon M (1987) Reproductive, growth and life history contrast between two species of grapsid crab Sesarma cinereum and $S$ reticulatum. Mar Biol 94:1-6

Spivak ED (1988) Moult and growth in Cyrtograpsus angulatus Dana (Decapoda, Brachyura). J Nat Hist 22:617-629

Spivak ED (1999) Effects of reduced salinity on juvenile growth of two co-occurring congeneric grapsid crabs. Mar Biol 134:249-257

Spivak ED, Politis MA (1989) High incidence of limb autotomy in a crab population from a coastal lagoon in Buenos Aires province, Argentina. Can J Zool 67:1976-1985

Spivak ED, Anger K, Luppi TA, Bas C, Ismael D (1994) Distribution and habitat preferences of two grapsid crab species in Mar Chiquita lagoon (Province of Buenos Aires, Argentina). Helgol Meeresunters 48:59-78 
Spivak ED, Anger K, Bas C, Luppi TA, Ismael D (1996) Size structure, sex ratio, and breeding season in two intertidal grapsid crab species from Mar Chiquita lagoon, Argentina. Nerítica 10:7-26

Tagatz ME (1968) Growth of juvenile blue crabs, Callinectes sapidus Rathbun, in the St. Johns River, Florida. Fish Bull 67:281-288

Tunberg BG, Creswell RL (1991) Development, growth, and survival in the juvenile Caribbean king crab Mithrax spinosissimus (Lamarck) reared in the laboratory. J Crustac Biol 11:138-149

Tweedale WA, Bert TM, Brown SD (1993) Growth of postsettlement juveniles of the Florida Stone Crab, Menippe mercenaria (Say) (Decapoda: Xanthidae), in the laboratory. Bull Mar Sci $52: 873-885$
Valero J, Luppi TA, Iribarne O (1999) Size as indicator of swimming speed of crab megalopae. J Shell Res 18:663666

Willason SW (1981) Factors influencing the distribution and coexistence of Pachygrapsus crassipes and Hemigrapsus oregonensis (Decapoda: Grapsidae) in a California Salt Marsh. Mar Biol 64:125-133

Yatsuzuka K, Meruane J (1987) Growth and development, especially on external sexual characters of Portunus (Portunus) pelagicus (Linné) (Crustacea, Brachyura). Rep Usa Mar Biol Inst Kochi Univ 9:1-38

Zar JH (1984) Biostatistical analysis, 2nd edn. Prentice Hall, Englewood Cliffs, N.J. 